Syntax Literate : Jurnal Ilmiah Indonesia p-ISSN: 2541-0849

e-ISSN : 2548-1398

Vol. 5, No. 5 Mei 2020

\title{
ANALISIS APLIKASI PENGAKUAN PENDAPATAN MURABAHA DAN MUDARABA DENGAN KUALITAS LAPORAN KEUANGAN ISLAM
}

\author{
Jaelani dan Yudi Febriansyah \\ Universitas Kuningan (UNIKU) \\ Email: jaelani@uniku.ac.id dan yudidoey81@gmail.com
}

\begin{abstract}
The purpose of this research is to analyze the extent to which the relationship Revenue Recognition Application of Murabaha and Mudaraba with Quality Islamic of Financial Statements on Sharia Islamic Bank in the district of Kuningan. To prove the hypothesis that has been formulated, researcher use the verifikative method and descriptive analyze, it is a reseach use the proving to test the result of the descriptive reseach hypothesis using the statistic calculation so that it is going to get the result of the rejected or received of its proving hypothesis. Based on the desciptive research achieved that the application of revenue recognition murabaha, the application of revenue recognition mudaraba, and quality islamic of financial statements in the very high category level. The result of t test show that the application of revenue recognition murabaha and the application of revenue recognition mudaraba have relationship with quality Islamic of financial statements.
\end{abstract}

Keywords: the application of revenue recognition murabaha, the application of revenue recognition mudaraba, quality islamic financial statements

\section{Abstrak}

Tujuan dari penelitian ini adalah untuk menganalisis sejauh mana hubungan tersebut adalah Aplikasi Pengakuan Pendapatan Murabahah dan Mudharabah dengan Kualitas Laporan Keuangan Syariah pada Bank Syariah Syariah di Kabupaten Kuningan. Untuk membuktikan hipotesis yang telah dirumuskan, peneliti menggunakan metode verifikasi dan analisis deskriptif, penelitian ini menggunakan pembuktian untuk menguji hasil hipotesis penelitian deskriptif dengan menggunakan perhitungan statistik sehingga akan mendapatkan hasil dari ditolak atau diterima dari hipotesis pembuktiannya. Berdasarkan penelitian deskriptif diperoleh bahwa penerapan pengakuan pendapatan murabahah, penerapan pengakuan pendapatan mudharabah, dan kualitas laporan keuangan syariah dalam kategori sangat tinggi. Hasil uji t menunjukkan bahwa penerapan pengakuan pendapatan murabahah dan penerapan pengakuan pendapatan mudharabah memiliki hubungan dengan kualitas laporan keuangan syariah.

Kata kunci: penerapan murabahah pengakuan pendapatan, penerapan mudharabah pengakuan pendapatan, kualitas laporan keuangan islam. 


\section{Pendahuluan}

Perekonomian yang baik dari suatu negara ditandai dengan berkembangnya banyak perusahaan-perusahaan dan industri-industri. Perusahan dan industri inilah yang nantinya akan memegang peranan yang penting dan strategis di dalam menggerakan usaha guna terciptanya landasan yang kokoh bagi tahapan pembangunan industri nasional. Selain dari industri dan perusahaan yang dapat memajukan perkembangan ekonomi nasional adalah perkembangan di dunia perbankan.

Bank adalah sebuah lembaga intermediasi keuangan, umumnya didirikan dengankewenangan untuk menerima simpanan uang, meminjamkan uang, dan menerbitkan promes atau yang dikenal sebagai bank note. Katabankberasal daribahasa Italiabancaberarti tempat penukaran uang (Munajim \& Anwar, 2016).

Pada dasarnya sistem keuangan dan perbankan syariah adalah merupakan bagian konsep yang lebih luas tentang ekonomi Islam, dimana tujuannya adalah untuk memperkenalkan dan menerapkan nilai etika Islam ke dalam lingkungan ekonomi, maka sistem keuangan dan perbankan bagi kebanyakan umat Islam adalah bukan sekedar transaksi yang sifatnya komersial tapi mempunyai unsur ibadah. Persepsi Islam dalam transaksi finansial yang sesuai dengan syariat Islam itu dipandang baik oleh banyak kalangan muslim maupun non muslim, kemampuan bank syariah dalam menarik investor dengan sukses bukan hanya bergantung pada tingkat dan lembaga yang menghasilkan keuntungan banyak, tetapi juga pada persepsi bahwa lembaga keuangan tersebut secara sungguh-sungguh menerapkan syariat Islam dalam setiap transaksi juga dalam kegiatan operasionalnya.

Karakteristik kualitas laporan keuangan syariah merupakan ciri khas yang membuat informasi dalam laporan keuangan syariah beruguna bagi pemakai. Apabila dilihat dari segi kualitas berdasarkan Panduan Standar Akuntansi (PSAK) menurut (Wasilah, 2013).

Oleh karena itu, semua bank syariah harus memiliki laporan keuangan berbasis syariah yang berkualitas sesuai dengan prinsip akuntansi syariah yang dinyatakan dalam Pernyataan Standar Akuntansi Keuangan (PSAK) tentang entitas syariah apabila dihubungkan dengan pencatatan pengakuan pendapatan murabahah dan pengakuan pendapatan mudharabah. Namun keberadaan bank-bank syariah yang ada di Kabupaten Kuningan kurang begitu dipahami, baik cara kerjanya maupun produk-produk bank yang ditawarkan kepada masyarakat, hal ini akan berdampak pada kualitas laporan keuangan yang ada pada Bank-bank syariah di Kabupaten Kuningan itu sendiri. Oleh karena itu, penulis tertarik untuk melakukan penelitian tentang penerapan pengakuan pendapatan murabahah dan mudharabah hubungannya dengan kualitas laporan keuangan berbasis syariah pada Bank Syariah di Kabupaten Kuningan.

\section{Metode Penelitian}

Metode penelitian yang digunakan dalam penelitian ini adalah metode deskriptif analitis dan metode verifikatif. Metode deskriptif dalam penelitian ini digunakan untuk menggambarkan pengakuan pendapatan murabahah, pengakuan pendapatan 
mudharabah dan kualitas laporan keuangan berbasis syariah yang ada pada bank-bank syariah di Kabupaten Kuningan. Penggunaan metode verifikatif pada dasarnya ingin menguji kebenaran dari suatu hipotesis yang dilakukan melalui pengumpulan data, dimana dalam penelitian verifikatif ini bertujuan untuk mengetahui "Hubungan pengakuan pendapatan murabahah dan pengakuan pendapatan mudharabah dengan kualitas laporan keuangan berbasis syariah yang ada pada bank-bank syariah di Kabupaten Kuningan".

(Arikunto, 2010) berpendapat bahwa: "Populasi adalah keseluruhan subjek penelitian". Berdasarkan pengertian tersebut, maka yang menjadi populasi dalam penelitian ini adalah karyawan Bank Syariah yang ada di Kabupaten Kuningan yaitu staff Bank Syariah Mandiri (BSM) sebanyak 15 orang dan staff Bank Jabar Banten (BJB) Syariah sebanyak 17 orang. Jadi populasi dalam penelitian ini sebanyak 32 orang. Berdasarkan hal tersebut, maka sampel yang digunakan dalam penelitian ini adalah staff Bank Syariah Mandiri (BSM) sebanyak 5 responden dan staff Bank Jabar Banten (BJB) Syariah sebanyak 5 responden. Jadi jumlah sampel dalam penelitian ini adalah sebanyak 10 responden.

Teknik analisis data dalam penelitian ini menggunakan Uji Validitas, Reliabilitas dan korelasi rank spearman. Uji Validitas merupakan data yang digunakan untuk mengetahui sejauh mana alat ukur yang digunakan dapat mengukur apa yang ingin diukur. Prosedur untuk melakukan uji validitas instrumen dapat. Data pada penelitian ini merupakan data ordinal maka perhitungan koefisien korelasi menurut (Maman, 2011) menggunakan rumus koefisien korelasi Spearman Rank.

$$
\rho=1-\frac{6 \Sigma D_{i}^{2}}{n\left(n^{2}-1\right)}
$$

Dimana:

$\begin{array}{lll}\rho & = & \text { Koefisien korelasi Spearman Rank } \\ \mathrm{n} & = & \text { banyaknya ukuran sampel } \\ \Sigma D_{i}^{2} & = & \text { jumlah kuadrat dari selisih rank variabel x dengan rank variabel y }\end{array}$

Menurut (Umar, 2003) "reliabilitas adalah suatu angka indeks yang menunjukkan konsistensi suatu alat pengukuran di dalam mengukur gejala yang sama."

Metode untuk mencari reliabilitas intern dengan rumus Cronbach's Alpha menurut (Arikunto, 2010) dalam (Maman, 2011) adalah sebagai berikut:

$$
\mathrm{r}_{11}=\left(\frac{k}{k-1}\right) \cdot\left(1-\frac{\sum \sigma_{b}^{2}}{\sigma_{t}^{2}}\right)
$$

Dimana:

$\begin{array}{ll}\mathrm{r}_{11} & =\text { Reliabilitas instrumen } \\ \mathrm{k} & =\text { Banyak butir/pertanyaan } \\ \Sigma \sigma_{b}^{2} & =\text { Jumlah varians bulir }\end{array}$


$\sigma_{t}^{2} \quad=$ Varians total

(suatu instrumen dinyatakan reliabel apabila alphanya $(\sigma)>0,60$ )

Adapun rumus statistik yang penulis gunakan adalah sebagai berikut :

$$
\mathrm{rs}=\frac{\sum \chi^{2}+\sum y^{2}-\sum d i^{2}}{2 \sqrt{\left(\sum x^{2}\right)\left(\sum y\right)^{2}}}
$$

(Maman, 2011)

Keterangan :

rs $=$ Koefisien korelasi Rank Spearman

$\Sigma \times 2=$ Jumlah nilai pengamatan item kuadrat

$\Sigma$ y2 $=$ Jumlah nilai pengamatan total kuadrat

$\Sigma$ di2 = Jumlah kuadrat dari selisih antara variabel $\mathrm{x}$ dengan $\mathrm{y}$

Hipotesis dapat didefinisikan sebagai jawaban sementara terhadap rumusan masalah yang berupa pernyataan tentang dua hubungan variabel atau lebih, perbandingan, atau variabel mandiri (Sanusi, 2011).

\section{Hasil dan Pembahasan}

1. Hubungan Penerapan Pengakuan Pendapatan Murabahah dengan Kualitas Laporan Keuangan Berbasis Syariah.

Dari hasil penelitian terlihat bahwa koefisien korelasi antara variabel $\mathrm{X}_{1}$ (Penerapan Pengakuan pendapatan murabahah) dengan variabel Y (kualitas laporan keuangan berbasis syariah) adalah sebesar -0,651. Jika dikaitkan dengan pedoman taksiran koefisien korelasi terlihat bahwa nilai koefisien korelasi tersebut termasuk dalam kategori sedang yakni berada pada koefisien 0,40-0,699 artinya bahwa hubungan antara Penerapan Pengakuan pendapatan murabahah dengan kualitas laporan keuangan berbasis syariah pada Bank Syariah di Kabupaten Kuningan adalah cukup kuat.

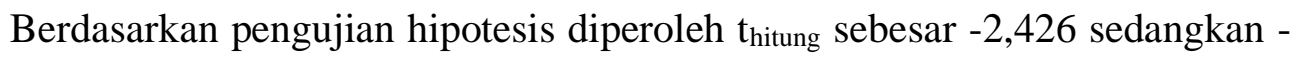
$\mathrm{t}_{\text {tabel }}$ untuk $\mathrm{n}-2=8$ pada $\propto=0,05$ adalah $-1,859$. Hal ini menunjukan $\mathrm{t}_{\text {hitung }}-2,426$ lebih kecil dari - $t_{\text {tabel }}-1,859$ sehingga Ho ditolak dan Ha diterima. Dengan demikian, hipotesis yang penulis ajukan diterima, artinya Penerapan Pengakuan pendapatan murabahah mempunyai hubungan dengan kualitas laporan keuangan berbasis syariah.

2. Hubungan Penerapan Pengakuan Pendapatan Mudharabah dengan Kualitas Laporan Keuangan Berbasis Syariah

Dari hasil penelitian, terlihat bahwa koefisin korelasi antara variabel $\mathrm{X}_{1}$ (Penerapan Pengakuan pendapatan mudharabah) dengan variabel Y (kualitas laporan keuangan berbasis syariah) adalah sebesar 0,656. Jika dikaitkan dengan pedoman taksiran koefisien korelasi terlihat bahwa nilai koefisien korelasi tersebut termasuk dalam kategori sedang yakni berada pada koefisien 0,40 - 0,699 artinya bahwa hubungan antara Penerapan Pengakuan pendapatan mudharabah dengan 
kualitas laporan keuangan berbasis syariah pada Bank Syariah di Kabupaten Kuningan adalah cukup kuat.

Berdasarkan pengujian hipotesis diperoleh thitung sebesar 2,458 sedangkan $\mathrm{t}_{\text {tabel }}$ untuk $\mathrm{n}-2=8$ pada $\propto=0,05$ adalah 1,859 . Hal ini menunjukan $\mathrm{t}_{\text {hitung }} 2,458$ lebih besar dari tabel 1,859 sehingga Ho ditolak dan Ha diterima. Dengan demikian, hipotesis yang penulis ajukan diterima, artinya Penerapan Pengakuan pendapatan mudharabah mempunyai hubungan dengan kualitas laporan keuangan berbasis syariah.

\section{Kesimpulan}

Gambaran mengenai penerapan pengakuan pendapatan murabahah, penerapan pengakuan pendapatan mudharabah dan kualitas laporan keuangan berbasis syariah berada pada kategori sangat tinggi. Ini berarti dalam pelaksanaannya, mayoritas staff pegawai bank syariah di Kabupaten Syariah telah melakukan pencatatn sesuai dengan Pernyataan Standar Akuntansi Keuangan (PSAK) yang berlaku.

Penerapan pengakuan pendapatan murabahah mempunyai hubungan dengan kualitas laporan keuangan berbasis syariah artinya penerapan pengakuan pendapatan murabahah yang sesuai PSAK akan membuat laporan keuangan berbasis syariah yang berkualitas.

Penerapan pengakuan pendapatan mudharabah mempunyai hubungan dengan kualitas laporan keuangan berbasis syariah artinya penerapan pengakuan pendapatan mudharabah yang sesuai PSAK akan membuat laporan keuangan berbasis syariah yang berkualitas. 
Jaelani dan Yudi Febriansyah

\section{BIBLIOGRAFI}

Arikunto, Suharsimi. (2010). Prosedur penelitian. Jakarta: rineka cipta.

Maman, Sambas Ali Dan. (2011). Analisis Korelasi, Regresi dan Jalur. Bandung: Pustaka Setia.

Munajim, Ahmad, \& Anwar, Saeful. (2016). Faktor Yang Mempengaruhi Keputusan Menjadi Nasabah Bank Syariah. Syntax Literate; Jurnal Ilmiah Indonesia, 1(2), 41-52.

Sanusi, Anwar. (2011). Metodologi penelitian bisnis. Jakarta: Salemba Empat.

Umar, Husein. (2003). Metodologi penelitian untuk skripsi dan tesis bisnis. Jakarta: PT. Gramedia Pustaka.

Wasilah, Sri Nurhayati Dan. (2013). Akuntansi Syariah Di Indonesia Edisi 3. Jakarta: Salemba Empat. 